\title{
NÃO PODEIS SERVIR A DEUS E A MAMMON - CONSIDERAÇÕES SOBRE FILOSOFIA DO CAPITALISMO EM WALTER BENJAMIN E SUAS CRITICAS SOBRE A SOCIEDADE BURGUESA
}

Otavio Barduzzi da Costa

\begin{abstract}
RESUMO
Este trabalho pretende tecer considerações a partir das ideias de Walter Benjamin sobre a Gênese e deslocamentos, na hegemonia do capitalismo histórico, em especial do seu texto "o capitalismo como religião", dentre outros e outros autores. Sendo a Religião como núcleo ético mítico de toda civilização, esse trabalho, dentre outros assuntos, há de abordar os entrelaçamentos entre economia e religião, o substrato religioso do capitalismo e o capitalismo como fenômeno essencialmente religioso. No pensamento de Walter Benjamin o Capitalismo é como uma religião da vida cotidiana. Pretende-se também fazer reflexões no sentido de uma crítica da relação entre religião e secularização e a sociedade burguesa.
\end{abstract}

Palavras-Chave: Capitalismo. Religião. Burguesia. Walter Benjamin.

\section{YOU CAN NOT SERVE GOD AND MAMMON - CONSIDERATIONS ON THE PHILOSOPHY OF CAPITALISM IN WALTER BENJAMIN AND HIS CRITIQUES OF BOURGEOIS SOCIETY}

\begin{abstract}
This paperwork intends to make considerations from Walter Benjamin's ideas about the Genesis and evaluation in hegemony of historical capitalism, especially in his text "capitalism as religion", among others, and other authors. Religion as being the mythical ethical core of every civilization, this work, among other things, intends to address the entanglements between economics and religion the religious subtract of capitalism and see the capitalism as essentially religious phenomenon. In The thought of Walter Benjamin ideas, Capitalism is like religion of everyday life. We intended to also make reflections towards a critique of the relationship between religion and secularization and bourgeois society.
\end{abstract}

Key- words: Capitalism. Religion. Bourgeois. Walter Benjamin .

Sociólogo, filósofo e mestre em filosofia pela UNESP, é doutorando em ciências sociais pela UNESP e doutorado em ciências da religião pela UMESP- Universidade Metodista de São Paulo, é professor na pós graduação de antropologia da Universidade do Sagrado Coração nas áreas de antropologia e Filosofia. Bolsista da CNPq. Brasileiro, residente em São Paulo - SP. Email: joebarduzzi@yahoo.com.br 
Um conto de Walter Benjamin para relembrar o dia de seu nascimento (15 de julho de 1892):

\begin{abstract}
"Uma luz.
Pela primeira vez estava a sós com minha amada. Era em uma pequena aldeia em um lugar bem desconhecido. Estava a sua espera em frente ao local em que estava hospedado - que não era o mesmo que o dela -, pois havíamos combinado um passeio noturno. Enquanto a aguardava, passei pela rua de cima à abaixo e então, foi que ao longe, entre as árvores, vi uma luz. 'Esta luz - pensei - não diz nada a quem a vê todos dias a noite, mas a mim, um estranho nesse lugar, diz muitas coisas'.

Em seguida, dei a volta e percorri todo o trajeto da rua da aldeia, coisa que continuei fazendo durante um certo tempo. Passados alguns minutos, regressava sempre ao mesmo ponto: a luz entre as árvores atraía meus olhos. Alguns instantes antes de reencontrar com a minha amada, quando me obriguei a parar a caminhada, olhei para trás uma vez mais e compreendi tudo: a luz que havia visto do nível do chão era a luz da lua que se levantava lentamente por entre as colinas ao longe."

(em "Historia y relatos")
\end{abstract}

Analisando o texto de Walter Benjamin: O capitalismo como Religião, chega-se a conclusão de que o capitalismo tem inúmeras condições socioculturais que remetem às dinâmicas religiosas. $O$ iminente pensador alemão declina que o capitalismo hoje tem a função de fazer cumprir o que antigamente as religiões prometiam: o paraíso. Prometem uma felicidade através do consumo, uma inclusão através do trabalho, um suposto sentido para a vida em seu exercício econômico e político. É claro que, como crítico da civilização (segundo Michel Löwy em prefácio à edição brasileira o capitalismo como religião), Benjamin vai avaliar inúmeros aspectos do capitalismo, mas principalmente, de como se constituiu na sociedade burguesa do ocidente.

O burguês capitalista, segundo Benjamin, é aquele que busca a frivolidade, a felicidade, a segurança, o que o capital pode comprar em sua propriedade privada. Ali, diz o autor, ele está no paraíso. Em suas memórias descreve a segurança do burguês em seu lar:

A miséria não tinha vez naqueles aposentos, nem mesmo a morte. Neles não havia lugar algum para morrer; por isso é que seus moradores morriam em sanatórios, mas a mobília, já na primeira linha de herdeiros, foi parar nas mãos de comerciantes. A morte não fora prevista para eles. Por isso, durante o dia, aqueles recintos pareciam

Sociólogo, filósofo e mestre em filosofia pela UNESP, é doutorando em ciências sociais pela UNESP e doutorado em ciências da religião pela UMESP- Universidade Metodista de São Paulo, é professor na pós graduação de antropologia da Universidade do Sagrado Coração nas áreas de antropologia e Filosofia. Bolsista da CNPq. Brasileiro, residente em São Paulo - SP. Email: joebarduzzi@yahoo.com.br 
tão aconchegantes e, à noite, tornavam-se o cenário de pesadelos. (BENJAMIN, 1987, 96)

A vida burguesa se confunde com a vida privada e com o egoísmo que só a vida privada pode produzir, não é mais a comunidade que interessa para a vida capitalista burguesa e sim sua segurança e vida privadas acumulada pelo seu trabalho, em suma, é a vida da sua família. O coletivo e o trabalho não importam para o burguês que vive na sua vida de lazer e frivolidade paradisíaca. Benjamin fala de quando começou talvez tal mentalidade:

\begin{abstract}
Pela primeira vez, o espaço em que vive o homem privado se contrapõe ao local de trabalho. Organiza-se no interior da moradia. $O$ escritório é o seu complemento. O homem privado, realista no escritório, quer que o interieur sustente as suas ilusões. Esta necessidade é tanto mais aguda quanto menos ele cogita estender os seus cálculos comerciais às suas reflexões sociais. Reprime ambas ao confirmar o seu pequeno mundo privado. Disso se originam as fantasmagorias do "interior", da interioridade. Para o homem privado, o interior da residência representa o universo. (BENJAMIN, 1987, 37)
\end{abstract}

As ilusões a que o autor se refere na citação acima é a falta de percepção do mundo lá fora, da miséria, da fome, da exploração, que ele sabe que existem, mas que, seguro no interior de sua casa, com sua mobília herdada, não quer conhecer. Se pudermos levar as condições para o mundo de hoje, a televisão e as comunicações Ihe nutrem a ilusão, dentro de sua sala, mostrando um mundo de sonhos, aventuras e fantasia. O celebre escrito não tratou exatamente da Televisão, sendo algo raro na sua época, nem é provável que tivesse assistido televisão, porém prevê que as câmeras poderiam estar em todo lugar e isso introduzir a um malefício na capacidade crítica do ser humano. Na sua crítica a reprodutibilidade da arte afirma que as câmeras, espalhadas em todos os lugares levam a um estado de letargia mental.

Outro elemento destacado é capacidade das câmeras (cinematográficas e fotográficas) de nos levar a um inconsciente óptico. "Aqui, a câmera intervém com os seus meios auxiliares, os seus "mergulhos" e subidas, as suas interrupções e isolamentos, os seus alongamentos e acelerações, as suas ampliações e reduções. A câmera leva-nos ao inconsciente óptico, tal como a psicanálise ao inconsciente das pulsões" (parênteses nossos, BENJAMIN, 1994, 178)

Sociólogo, filósofo e mestre em filosofia pela UNESP, é doutorando em ciências sociais pela UNESP e doutorado em ciências da religião pela UMESP- Universidade Metodista de São Paulo, é professor na pós graduação de antropologia da Universidade do Sagrado Coração nas áreas de antropologia e Filosofia. Bolsista da CNPq. Brasileiro, residente em São Paulo - SP. Email: joebarduzzi@yahoo.com.br 
Assim, seguros nas suas casas, na sua mobília, no seu mundo construído de fantasia, se sentem no seu paraíso construído, à custa do seu trabalho, com direito para desfrutar das benesses da proteção de Deus. A mitologia religiosa judaico cristã, dentre outras, chama sempre o paraíso de proteção, de morada. Na mentalidade Judaica, o Deus IEVE é escudo, fortaleza e broquel, na Bíblia Sagrada (1995, Salmos 18). Na bíblia cristã, no apocalipse, haverá no paraíso uma morada (1995, apocalipse 22). A mitologia nórdica, profundissimamente ligada ao imaginário protestante, põe como paraíso do guerreiro, o Valhalla, uma fortaleza onde há banquetes e lutas gloriosas. O conceito de fortaleza como paraíso está ligado a várias mitologias e religiões. Assim, na sua casa, ou na máxima popular, a casa de um homem é seu castelo. O burguês se sente no paraíso (CAMPBELL, 2001).

Note-se: uma casa, na mentalidade burguesa, é um direito para poucos. Apenas quem supostamente conquistou tem direito à moradia. A propriedade privada é tida como um direito divino e sagrado desde as revoluções burguesas. Esse é o direito mais sagrado para o burguês, mais do que a dignidade humana, mais do que a prometida igualdade e imaginária fraternidade.

A mentalidade burguesa, na sua falsa segurança, além de dinheiro, quer fama. Fama e fortuna, reconhecimento pelo seu trabalho, ou pelo seu dinheiro ou pela ilusão que se vende. Esse é o atual espírito do capitalismo. A imagem antes vendida pelo cinema, agora universalizada pela televisão, é o que Benjamim criticava, através do crítico de arte Georges Duhamel, "que detesta o cinema e nada sabe do seu significado, mas percebe algo das suas estruturas" $(1994,181)$, estruturas essas que Benjamin aceita serem perversas e vendedoras de uma ilusão, salvo raras exceções, na sua produção. Relembrando o crítico francês Duhamel: "em sua opinião (a de Duhamel) o cinema é "um passatempo para a ralé, uma diversão para criaturas iletradas, miseráveis, gastas pelo trabalho e consumidas pelas preocupações...um espetáculo que não exige concentração, nem pressupõe qualquer capacidade de esperança, a não ser a esperança ridícula de vir a ser estrela em Los Angeles" (idem). Assim há um constante espraiamento da ilusão e do 
amortecimento intelectual para Benjamin. Pensamos hoje que esse pode ser multiplicado pela televisão. Todos pensam que podem viver uma vida mostrada pelos meios de comunicação e o burguês capitalista quer viver exatamente essa sua forma de paraíso.

O capitalismo, como afirma Bresser-Pereira (2011), não é só uma forma econômica de relações de produção, mas se configurou através da história como forma política e cultural. Afirma Bresser-Pereira: "A revolução capitalista foi uma transformação econômica, social e política, de tal forma importante, que podemos dividir a história em duas grandes fases: a antiga e a moderna, ou a pré-capitalista e a capitalista" (BRESSER-PEREIRA, 2011, 2). Assim o capitalismo, mais do que uma relação econômica, é uma configuração histórica de multi relações humanas, que permeia a mentalidade do ocidente (pós?) moderno. Vivemos no capitalismo.

O capitalismo é uma religião, segundo Benjamim, que culpabiliza. Lembrando a culpa, na cultura judaico-ocidental, a culpa se inicia quando o povo no deserto, desobedecendo a Moisés, adorara um bezerro de ouro. Mas o homem agora alimentou e adora esse bezerro, já crescido e posto simbolicamente no centro do capital, em Wall Street, como um bezerro já fortalecido, um boi de ouro. O povo agora não sente culpa em adorar o capital. Para Benjamin, o capitalismo é uma religião, na qual o culto se emancipou de um objeto de adoração e passou a ser o seu próprio ato de consumir, sem culpa, tabus, nem pecados, ao contrário das religiões. E portanto, sem redenção. Há só felicidade prometida (mas raramente alcançada). Então, do ponto de vista da fé, o capitalismo não tem nenhum objeto: acredita no puro crédito, no dinheiro a ser alcançado, no lucro que virá, nesse porvir. O lucro é encarado pelo burguês como a promessa de paraíso.

A religião do capital é nova. Porque não há sacrifício messiânico, a culpa segundo os nãos existentes, mas reais cânones dessa religião, é de cada um que fracassa, que não enriquece. O pobre não é visto como aquele que não teve oportunidade, mas como aquele fracassado, provavelmente pecador. $O$ capitalista pensa: se o pobre está nessa situação é porque é ruim e mal, e deve ser ladrão, diante dele devo tomar conta da minha carteira. O pobre é culpado

Sociólogo, filósofo e mestre em filosofia pela UNESP, é doutorando em ciências sociais pela UNESP e doutorado em ciências da religião pela UMESP- Universidade Metodista de São Paulo, é professor na pós graduação de antropologia da Universidade do Sagrado Coração nas áreas de antropologia e Filosofia. Bolsista da CNPq. Brasileiro, residente em São Paulo - SP. 
por seu próprio fracasso. O self-made man é o santo, o herói mitológico que trabalhou e merece sua casa-fortaleza. Quanto mais rico, mais agraciado. É clara a relação apontada por Weber, na sua ética protestante. Só que ao contrario do capitalista de Weber, que vivia num ascetismo intramundano, o burguês moderno quer aproveitar todas as benesses que os meios de comunicação querem the vender.

O inferno é a pobreza. Na visão do capitalista burguês, não ter dinheiro e fama é o pior dos castigos. O destino de cada um é ligado ao caráter, mas o caráter valorizado pelo burguês nada tem a ver com o amor ao próximo ou bondade, mas sim o caráter deve ser ambição, espírito de acumulo. Egoísmo e esperteza são os caracteres valorizados. O pobre vive no inferno. A pior coisa para o capitalista é não ter bens. O pobre é considerado não como apenas infortunado, mas de mal caráter, como bandido ou que merece estar em situação de pobreza. Há o predomínio do pensamento de "só é pobre quem quer".

\section{O culto}

Há um culto ao dinheiro. O objeto de desejo e de adoração não é algo transcendente, mas o vil metal. $O$ deus adorado se torna o dinheiro (AGAMBEN, 2012). O artista Andy Warhol, sensível ao seu tempo, pintou, em um quadro, uma nota de um dólar, e ao invés da expressão "in God we Trust" (em Deus confiamos) ele escreveu "This is your god", esse é o seu Deus. No capitalismo não há perdão de dívidas. Há garantias de dividas, que se tornam novos lucros. No capitalismo, não se pode pagar com sangue do Cordeiro suas dívidas. Também é pouco provável que uma divindade vá pagar as dívidas creditícias. Disso só decorre a descrença na força de Deus e a crença na força do capital.

A culpabilização da religião Cristã se dá pelo assassinato de Cristo, no Calvário. Não há culpa no capitalismo, apesar das várias vítimas que ele gera, por ser uma religião sem responsável e sem Deus antropomórfico a quem culpar. A religião tem a função de ser o fundamento da cosmovisão que legitima a ordem social vigente, assim o capitalismo como religião legitima a 
ordem do lucro. E essa ordem lida com uma cosmovisão intensa: a de continuar lucrando a qualquer preço.

Há um vácuo na objetividade do mundo, que está no cerne da visão sistêmica de mundo, e na inversão dos objetos e do papel do humano. Agora são os objetos, e não as pessoas que fazem as coisas. Benjamin (1994) em sua "Magia e técnica, arte e técnica" considerara o risco das pessoas serem substituídas por coisas, e de que os objetos é que fazem tudo. E o dinheiro é quem faz. Ele (o capitalismo) tira do homem a sua responsabilidade do uso das maquinas e do dinheiro. Esta inversão teórica desculpabiliza o ser humano. $\mathrm{O}$ ser humano não é o ser que constrói o mundo em Deus. No capital, o ser humano é um objeto a ser usado, e quem constrói o mundo agora passa a ser o dinheiro, em uma inversão da objetividade do agir do homem.

Benjamin $(1987,69)$ evoca os termos "dívida" e "culpa". Segundo uma perspectiva histórica de que não podemos separar esses dois termos, no sistema da religião capitalista, a "culpa mítica," da dívida econômica, surge como algo sem culpabilização. O capitalismo é um culto que não resgata, mas deixa um sentimento de culpa apenas nos sensíveis. Neste sentido, este sistema religioso, surge após o colapso do cristianismo. Uma enorme sensação de culpa, incapaz de se render, deu proveito a esse culto, e sua culpa, em vez de ser resgatada, é universalizada, gravada na consciência, até que o próprio Deus é preso na rede "culpa", de modo que, finalmente, ele próprio está interessado em sua expiação. Não se pode, portanto, esperar que isso aconteça no próprio culto, ou na reforma dessa religião, uma vez que teria de agarrar-se a algo sólido que aparentemente não existe na história (isso seria o verdadeiro cristianismo, mas foi rejeitado como mito). A essência deste movimento religioso que é o capitalismo é parte de sua capacidade de percorrer todo o caminho, de fornecer todas as repostas finais, até culpar a Deus $^{1}$, para atingir o estado de desespero, no mundo.

Em certa divagação, Hinkelammert $(2005,113)$ inicia com uma frase bem emblemática: “ o Capitalismo surge com a pretensão de ser a instância de

\footnotetext{
${ }^{1}$ É comum no discurso capitalista culpar a Deus e não ao homem pelas misérias humanas decorrentes das relações de exploração.

Sociólogo, filósofo e mestre em filosofia pela UNESP, é doutorando em ciências sociais pela

UNESP e doutorado em ciências da religião pela UMESP- Universidade Metodista de São Paulo, é professor na pós graduação de antropologia da Universidade do Sagrado Coração nas áreas de antropologia e Filosofia. Bolsista da CNPq. Brasileiro, residente em São Paulo - SP. Email: joebarduzzi@yahoo.com.br
} 
salvação". Ele atribui o começo desse ao mercantilismo exploratório colonial, porém sua ideologia é obra de Adam Smith. Acentua seriamente que as posições cristas dos primeiros séculos faziam uma explanação teológica de Mateus 6:24 com a citação de Jesus : "Não se pode servir a Deus e a Mammon ${ }^{2 "}$. Porém o que ocorreu foi o contrário. Ocorreu uma espiritualidade do mercado. Hoje é o capital e o dinheiro que prometem o paraíso e a felicidade, não mais as coisas espirituais.

Com Adam Smith o mercado é visto como um Deus dotado de vontade, um ser supostamente inteligente. Adam Smith não aplica a função de Divindade ao mercado, mas seu discurso revela em sub-tom, como se o mercado tivesse uma vontade, um equilíbrio, que faz parte da herança organicista do pensamento moderno. É um Deus ex-machina, que aparece na história, para tentar amarrar as pontas soltas e não consegue. Um patético, cruel e inventado Deus que só servia aos interesses burgueses.

Esse é o pressuposto da modernidade civilizatória, a qual Benjamin vem criticar: critica à moral burguesa e sua formação e expressões, seja no cotidiano, na arte, na indústria e em outras manifestações.

\section{A (in)justiça do mercado.}

O mercado, de tudo toma conta, e passa a ser o regulador das relações sociais. Mais do que isso, passa a ser o centro das sociedades, se infiltrando no dia-a-dia das pessoas. A referência passa a ser mercado e recursos: mercado de trabalho, de capitais, de alimentos, da droga, mercado matrimonial, religioso e de bens simbólicos. Não há expressão mais assustadora, por exemplo, do que recursos humanos. Ou seja, para a produção de bens e serviços, o ser humano é reduzido a um recurso, um bem

\footnotetext{
2 Jesus, como Rabi judeu, combatia o império e seu discurso de riquezas, para tanto em suas parábolas explicava de um modo que as pessoas pudessem entender, Mammon era um termo hebraico que significava avareza e também a deidade mesopotâmica das riquezas, a qual a lógica judaica combatia como falsos deuses. Goethe também apresenta Mammon com ambos significados, enquanto crítica, Benjamin ao analisar a obra de Fausto utiliza o termo Mammon para se referir aos males do capitalismo.
}

Sociólogo, filósofo e mestre em filosofia pela UNESP, é doutorando em ciências sociais pela UNESP e doutorado em ciências da religião pela UMESP- Universidade Metodista de São Paulo, é professor na pós graduação de antropologia da Universidade do Sagrado Coração nas áreas de antropologia e Filosofia. Bolsista da CNPq. Brasileiro, residente em São Paulo - SP. 
substituível a qualquer momento. Outra expressão odiosa é "regime de bens" num casamento, o casamento que é algo espiritual, de uma relação sagrada e de amor entre duas pessoas, é reduzido a uma garantia contratual, a um contrato frio de negócios.

Sobre o casamento Benjamin, em seu estilo peculiar, faz da crítica de uma obra de arte, uma crítica a uma situação, quando escreve sobre as "afinidades eletivas" de Goethe ${ }^{3}$, que per si, já é uma crítica ao modo de vida burguês. Para Benjamin, o casamento burguês, dotado de fortuna é um teatro de aparências, que leva as pessoas às falsas moralidades. As convenções sociais e jurídicas impedem o ser humano de viver plenamente os seus desejos por causa da culpa imposta pela sociedade, que retira a natureza do ser humano. Sobre isso Benjamin afirma:

Quando desaparece ao homem a vida supranatural, mesmo que ele não cometa nenhum ato imoral, sua vida se enche de culpabilidade. Porque ele é então cativo do simples fato de viver, que se manifesta no homem como culpa". (BENJAMIN, 2011, 45)

Nessa mesma obra Benjamin afirma que se pode buscar teor de verdade em obras de arte e que os conhecimentos artísticos, míticos, religiosos, dentre outros, podem emanar verdade, em sua análise: "o objetivo da crítica filosófica é mostrar que a função da forma artística é justamente converter em teores de verdade os teores históricos da coisa, que estão na raiz de toda obra significativa" (op. Cit, 67). Nessa mesma obra, ele chama atenção da aparência da beleza física feminina e seu poder, que notadamente, é levado ao grau de fragilidade e de puro desejo, pela mentalidade dos ricos, demonstrando a frivolidade de seu ideário, como se uma bela moça (ou moço) não pudesse ser nada além de admirável, por seu físico. Aproveitando-se disso Benjamin faz severa crítica ao imaginário da beleza em si e fora de si, mostrando que ela não é um poder como quer e deseja o pensamento capitalista.

3 Romance que causou escândalo na sociedade europeia do Sec. XIX, pois envolvia a separação de um casal e sua aproximação por pessoas amigas desse casal. O livro foi tido como uma ofensa à natureza externa e infração de normas contratuais legais. A dupla fratura é provocada pelo incessante interesse em criar e possuir a beleza que leva os personagens a passarem por cima das tradições, dos costumes, e da ordem natural.

Sociólogo, filósofo e mestre em filosofia pela UNESP, é doutorando em ciências sociais pela

UNESP e doutorado em ciências da religião pela UMESP- Universidade Metodista de São Paulo, é professor na pós graduação de antropologia da Universidade do Sagrado Coração nas áreas de antropologia e Filosofia. Bolsista da CNPq. Brasileiro, residente em São Paulo - SP. 
Benjamin ainda utiliza a crítica, nesta obra, sobre as dificuldades e danos que o sistema jurídico, através da lei positiva, faz à natureza humana, submetendo tudo ao seu poder. Pelo poder jurídico, todas as relações são garantias reduzidas a termos de negócios contratuais, inclusive o casamento (que deveria ser uma relação de amor), e o trabalho, a arte dentre vários outros valores ligados à natureza humana. $O$ poder jurídico se apresenta como um poder divino, atuando nas relações econômicas, pois ele efetiva o poder dos contratos, é a ira, o raio de destruição do deus Mammon ${ }^{4}$.

O direito é a materialização do mito e do ritual, nas sociedades modernas de profunda influência mítica Greco-romana. É o direito quem garante vidas e seus destinos, é um Deus encarnado na toga. O juiz tem o poder de decidir vidas, prender, soltar ou dividir os direitos sagrados de liberdade e propriedade, de influenciar como os pais devem criar filhos, como os casais devem ter sua moral sexual, como empresas e economia devem ser conduzidas, dentre inúmeros outros aspectos da realidade burguesa. Assim o direito se constitui um poder, na opinião de Benjamin um mau poder, ao querer se tornar potência e vontade, a regular todas as relações humanas. Benjamin torna o direito um "resíduo do plano demoníaco da existência humana" (1991b, 175). Bom lembrar que no mito judaico-cristão, o demônio ou satanás, queria tomar o lugar da potência divina querendo controlar o homem, oferecendo o conhecimento do bem e do mal e assim controlar a vontade humana, no lugar de Deus.

Assim o direito se apresenta como potência garantidora da violência e uma violência supostamente legitima, que entra, sobretudo, em ação, para garantir o Status quo, um direito que não pode ser questionado, pois não admite nenhuma outra forma de violência que não seja a sua legitimada. $\mathrm{Na}$ verdade, podemos ver isso em todo o ocidente. O direito entra em ação com violência eficaz para defender o capital. Basta dever algum dinheiro que logo e com força policial, o devedor vem recuperar o que é seu "por direito". Inclusive, se esse direito cruza com a dignidade, como no caso de retomada de posse de

\footnotetext{
${ }^{4}$ Mammon na mitologia mesopotâmica era o deus do dinheiro, atacado de forma veemente pelo Deus Judaico -Cristão.

Sociólogo, filósofo e mestre em filosofia pela UNESP, é doutorando em ciências sociais pela UNESP e doutorado em ciências da religião pela UMESP- Universidade Metodista de São Paulo, é professor na pós graduação de antropologia da Universidade do Sagrado Coração nas áreas de antropologia e Filosofia. Bolsista da CNPq. Brasileiro, residente em São Paulo - SP. 
terras improdutivas ou de moradias abandonadas, a retomada é sempre violenta e legalizada.

Assim o direito se torna um poder, um braço armado, com capa de legitimidade para afogar qualquer forma de resistência ou questionamento ao poder. O poder assim é inserido e garantido pelo econômico, na verdade poder jurídico e econômico é um só poder, um só deus, ou melhor, um deus de muitas faces, na verdade um monstro que ocupa o lugar do deus. Esse deus se apresenta sob a capa sagrada da justiça, oferece uma justiça falsa e assim toma o lugar do poder divino. Oferece um bem para fazer um mal:

No decorrer da história, houve uma inversão de tal monta que os
homens "confundiram" direito com justiça, aquele mascarando-se
com esta, conduzindo a humanidade a se enredar cada vez mais nas
teias da fatalidade : Equivocadamente, por causa de sua troca
enganosa com o mito da justiça, (...)determinou não apenas suas
relações, mas as relações dos homens com as normas jurídicas,
mas também com os deuses, conservou-se para além do tempo em
que se inaugurou a vitória sobre os demônios. (BENJAMIN, 1991b,
174)

O direito se torna aquilo que o poder econômico não pode demonstrar, que está sob risco de revolta. É uma ilusão criada, um teatro dos deuses para acalmar o homem. O direito se torna a expressão do poder, que é a característica intima da divindade. O poder econômico não pode se propor como poder aparente pois, para existir, depende da vontade do homem de ser rico, ou seja, de alcançar o poder da religião do capitalismo, e isso seria sacrilégio. Assim o poder é expresso pela relação jurídica, e não pela econômica, sendo a relação econômica vista como benesse dos falsos deuses, quando, na verdade, é sua própria característica ilusória. Por trás dessa máscara, esse teatro consolida seu poder e o braço armado da ira desse Deus. O seu lado negativo, que supostamente é neutro é cego, é visto como algo separado dele. Na verdade, o poder jurídico é o poder econômico e vice versa, mas nenhum fiel pode saber disso, deve-se preservar a ilusão. Através da ilusão, é que Zeus seduzia as belas mortais e através da ilusão, é que o demônio seduz os seres humanos. O direito cumpre a violência da transgressão de um direito existente, assim o direito é Apolo e Ártemis agindo a

Sociólogo, filósofo e mestre em filosofia pela UNESP, é doutorando em ciências sociais pela UNESP e doutorado em ciências da religião pela UMESP- Universidade Metodista de São Paulo, é professor na pós graduação de antropologia da Universidade do Sagrado Coração nas áreas de antropologia e Filosofia. Bolsista da CNPq. Brasileiro, residente em São Paulo - SP. 
favor de sua mãe Leto $^{5}$ (poder econômico), que tem aparência de modesta, mas na verdade tem uma vaidade terrível e quando desafiada manda sua vingança através do direito (BENJAMIN, 2011, 147).

O poder mítico em sua forma arquetípica é mera manifestação dos deuses. Não meio para seus fins, quase não manifestação de sua vontade, antes manifestação de sua existência. Disso, a lenda de Níobe oferece um excelente exemplo. É verdade que ação de Apolo e Ártemis pode parecer uma mera punição da transgressão de um direito existente. A hybris de Níobe conjura a fatalidade, não por transgredir a lei, mas por desafiar o destino - para uma luta na qual o destino terá de ser o vencedor, podendo engendrar, na vitória, um direito. Até que ponto o poder divino, no sentido da Antiguidade, não era o poder mantenedor da punição, fica patente nas lendas, onde 0 herói, por exemplo Prometeu, desafia o destino com digna coragem, luta contra ele, com ou sem sorte, e acaba tendo a esperança de um dia levar aos homens um novo direito. É, no fundo, esse herói e o poder jurídico do mito incorporado por ele que o povo tenta tornar presente, ainda nos dias de hoje, quando admira o grande bandido. A violência* portanto desaba sobre Níobe a partir da esfera incerta e ambígua do destino. Ela não é propriamente destruidora. Embora traga a morte sangrenta aos filhos de Níobe, ela se detém diante da vida da mãe, deixando-a - apenas mais culpada do que antes, por causa da morte dos filhos - como suporte mudo eterno da culpa, e também como marco do limite entre homens e deuses. Se esse poder imediato quer mostrar, em manifestações míticas, que é parente próximo do poder instituinte do direito ou lhe é idêntico, ele focaliza um problema deste poder, na medida em que este tinha sido caracterizado - na apresentação anterior da violência* da guerra como um poder* apenas dos meios. Ao mesmo tempo, esta relação promete esclarecer melhor o destino que em todos os casos está subjacente ao poder ${ }^{*}$ jurídico, e, num grande esboço, levar sua crítica a termo. A função do poder- violência, na institucionalização do direito, é dupla no sentido de que, por um lado, a institucionalização

\footnotetext{
${ }^{5} \mathrm{O}$ mito é assim : Níobe, filha de Tântalo e Dione e esposa de Anfião, rei de Tebas; conhecia muito bem - conforme se propalava - o histórico de Leto; principalmente, por ter cogitado exageradamente - em relação aos detalhes de seu sofrimento -; como se visasse o sentido existencial dessa deusa.

Leto (Latona), filha de Cronos (Saturno), por sua união com Zeus, gerara os gêmeos: Ártemis e Apolo, conforme um parto - deveras - difícil (em razão do ciúme e perseguição de Hera). Essa realização só se concretizou em Delos (onde a deusa, considerada "da noite"), se contorcendo em dores, durante nove dias, conseguiu conceber seus dois (e únicos) filhos. Níobe, revia tudo isso sem a mínima 'piedade', no entanto sob intenso orgulho (de si própria), pois, parira com a maior facilidade sete filhos e sete filhas, ou seja: Sípilo, Agenor, Fraédimo, Ismeno, Ulinito, Tântalo e Damasiction (os machos); e, Etoséia, Cleodosa, Astíoque, Ftia, Pelópia, Melibéia e Ogigia (as fêmeas). Assim se orgulhava de sua fertilidade e ofendeu Leto, Apolo e Artemis, obedecendo a ordem de sua mãe Leto, se vingaram cruelmente. Permanecendo alertas, quanto ao dia em que se mostrasse propício, pois, quando Apolo avistou os filhos de Níobe numa planície - se exercitando, matou cada um deles com suas flechas. De imediato, Níobe e suas filhas, deram conta da celeuma (ou do extermínio), caindo aos prantos sobre os corpos de seus entes queridos. Mas, tal atitude (geral entre elas) de nada adiantava, pois, nova saraivada de flechas - naquela instância - sob o comando de Artemis, decretou - também - a morte das sete filhas de Níobe. Trecho da obra VERNANT, 2010, 185.
}

Sociólogo, filósofo e mestre em filosofia pela UNESP, é doutorando em ciências sociais pela

UNESP e doutorado em ciências da religião pela UMESP- Universidade Metodista de São

Paulo, é professor na pós graduação de antropologia da Universidade do Sagrado Coração nas áreas de antropologia e Filosofia. Bolsista da CNPq. Brasileiro, residente em São Paulo - SP. Email: joebarduzzi@yahoo.com.br 
almeja aquilo que é instituído como direito, como o seu fim, usando a violência* como meio; e, por outro lado, no momento da instituição do fim como um direito, não dispensa a violência, ${ }^{*}$ mas só agora a transforma, no sentido rigoroso e imediato, num poder* instituinte do direito, estabelecendo como direito não um fim livre e independente de violência (Gewalt), mas um fim necessário e intimamente vinculado a ela, sob o nome do poder (Macht). A institucionalização do direito é institucionalização do poder e, nesse sentido, um ato de manifestação imediata da violência. A justiça é o princípio de toda instituição divina de fins, o poder (Macht) é o princípio de toda institucionalização mítica do direito.(...) (BENJAMIN, 2011, 147)

Brilhantemente Benjamin usa a figura do mito para explicar os fundos de verdade e de crítica da sociedade, o que ele já faz, largamente, com a literatura. Na religião do capital o homem se faz melhor que Deus "Não porque o encadeamento de culpa e expiação, que para o homem pagão é interminável, seja dissolvido pela purificação do homem penitente e sua reconciliação com o puro deus - mas porque, na tragédia, o homem pagão se dá conta de que é melhor que seus deuses." (BENJAMIN, 2011, 14) . Pois é uma religião pagã; adora-se um bezerro de ouro ${ }^{6}$, como nos dias de Moisés. É uma religião pagã, pois no fundo trata-se de um retrato do próprio homem, essa é a característica das religiões pré-monoteístas, segundo Cassirer (1977). O paganismo é uma expressão da vontade do próprio homem, enquanto as novas religiões são expressões do cosmo e do transcendente ao homem (embora não haja absolutos nesse campo).

\section{De como o capitalismo enquanto religião age hoje em dia}

É um pouco temerário comparar as ideias das análises de Benjamin, mais aplicáveis a Europa entre guerras do que ao resto do mundo, em especial, ao mundo latino americano, porém sua genialidade pode transcender tempo e espaço. Na verdade, a partir de seu texto passa-se a algumas considerações de como o capitalismo enquanto religião age hoje em dia. É

\footnotetext{
${ }^{6} \mathrm{Na}$ história bíblica, a rebeldia dos judeus, enquanto Moisés conversava com Deus no monte Horebe, os israelitas construíram um deus de ouro na forma de um bezerro, para se opor a rígida moralidade imposta por IEVE e fazer o que quiser, sobretudo contrariando suas ordens sexuais e financeiras. O mito serve para dizer que o homem cumpre sua egoísta vontade ao invés de obedecer a Deus. Assim se humaniza, e o retrato da humanização e construir deuses para si, renegando sua divindade e se assumindo como humano.
}

Sociólogo, filósofo e mestre em filosofia pela UNESP, é doutorando em ciências sociais pela UNESP e doutorado em ciências da religião pela UMESP- Universidade Metodista de São Paulo, é professor na pós graduação de antropologia da Universidade do Sagrado Coração nas áreas de antropologia e Filosofia. Bolsista da CNPq. Brasileiro, residente em São Paulo - SP. Email: joebarduzzi@yahoo.com.br 
claro que o capitalismo evoluiu muito desde o tempo de Benjamin, tal como sua intrínseca relação com os meios de comunicação e a evolução da acumulação flexível, mas os ideais burgueses continuam mais ou menos os mesmos, as considerações são inspiradas pelas ideias de Benjamin, mas as análises podem incluir ressalvas de tempo e espaço.

A obra de E. Durkheim (2000, 261) já afirma que: "não há religião sem comunidade (igreja)". O mercado, como religiã, marca a nova comunidade que é a sociedade moderna. As pessoas se reconhecem e se valorizam pelo poder de compra que tem. Uma pessoa de bem é aquele que tem poder de consumo.

A religião do mercado tem os seus comportamentos e dogmas. Como exemplo:

- $\quad$ O mercado é causa de desigualdades; assim é um produtor de vítimas, que ou são exploradas ou são vítimas da violência causada pela comunicação que leva desejos aos que não podem, e por isso roubam violentamente multiplicando as vítimas (MESSNER, ROSENFELD, 2000)

- O mercado, dentro da ordem capitalista mundial, gera concentração de riquezas nas mãos de poucos países e de poucos magnatas e desestruturação social e miséria para a maior parte da humanidade (HOFFMANN, 1994).

- Não é mais a fé que move céus e terra, é outra coisa a que é atribuída tal força. O lema fundamental é: "o dinheiro tudo pode, move o céu e a terra".

- A propaganda tem a função de uma felicidade salvífica. Se você não pode ter a mercadoria $X$ você não é feliz. Se você não tem mercadoria $e$ não pode ser bem sucedido, é um excluído e não é uma pessoa de bem.

- $\quad$ As mercadorias são representantes de desejos mais profundos da alma.

- A propaganda é uma autentica catequese, um ensinamento do que deve ou não ter para ser feliz.

- $\quad$ O culto dominical são os programas televisivos. 
- A grande festa anual é o natal. Não para comemorar o nascimento do Salvador, mas uma festa de consumo e presentes para a qual as crianças são educadas desde cedo.

- Os templos são as lojas.

- A peregrinação são as novas viagens; os grandes shoppings e cidades do consumo, e turismo, Disney World, Miami, Paris etc.

- Os sacerdotes são os que conhecem as regras do jogo, advogados, que garantem a propriedade privada e seu pagamento, economistas e banqueiros.

- As vestes rituais para participar da sociedade são as roupas de marca caríssimas tal como Ermenildo Zegna, Nike, Lacoste etc....quando se está vestido assim, o ser se torna benquisto na sociedade. Quando não veste, é um excluído dela.

- A ética principal é o interesse pessoal, egoísta, competitivo com sede de crescimento financeiro patológico.

Assim, se constrói e se produze a religião da espiritualidade do mercado.

Tal religião promete felicidade a todos os que a consomem. Essa promessa falha fragorosamente uma vez que poucos tem o poder de ter tudo 0 que se apresenta para consumo. As mercadorias tem status divinos e de bênçãos. A elas se adjudicam características salvíficas. É no contanto com o novo sagrado que surge uma nova ética de ser: a da competição e concorrência no mercado, seu semelhante passa a ser visto como concorrente. A mística que move as pessoas no capitalismo é ganhar dinheiro para ganhar mais dinheiro; comprar mais, comprar mais para consumir mais e mais. É no poder de consumo, que se mede o caráter de uma pessoa segundo essa lógica. O ser humano é medido em Ter e não em Ser. Numa sociedade assim, a pessoa tem a sua dignidade reconhecida nas relações mercantis, no mercado. Os pobres são marginalizados exatamente pela sua impossibilidade de acesso ao mercado. Esses milhares que são a maioria do mundo são invisíveis e reduzidos a meros problemas políticos, seres humanos incapacitados de participar do acesso aos bens que eles mesmos produzem Sociólogo, filósofo e mestre em filosofia pela UNESP, é doutorando em ciências sociais pela UNESP e doutorado em ciências da religião pela UMESP- Universidade Metodista de São Paulo, é professor na pós graduação de antropologia da Universidade do Sagrado Coração nas áreas de antropologia e Filosofia. Bolsista da CNPq. Brasileiro, residente em São Paulo - SP. 
em um total estado de alienação, alienação do produto de seu trabalho, alienação causada pelo sistema de propaganda. Na tentativa desesperada de sobreviver e de manter seus filhos, perde-se o amor ao próximo.

O mercado disfarça sua finalidade (o lucro), em respeito a certos direitos humanos, porém alcançar a plenitude desses direitos se torna impossível, uma vez que a finalidade do mercado não é alcançar esses direitos (meio ambiente ecologicamente equilibrado, justiça, saúde, educação pleno emprego etc..), e sim o lucro. Desse modo a finalidade do homem (e não só da empresa) também passa a ser o lucro, impossível não lembrar do epíteto de Hobbes, como nessa lógica pessoal vai surgir o homem: a reposta é apenas: "como lobo do homem", como concorrente de seu semelhante.

A liberdade humana nessa relação fica ilusória e prejudicada, uma vez que o homem só tem liberdade para consumir. Hinkelammert, $(2005,122)$ fala da liberdade de escolher entre uma sociedade de plena convivência e uma sociedade Hobbesiana, mas não há como agir sobre tais supostas liberdades, frente a força poderosa do capital. O próprio autor diz que a democracia está a serviço do capital (idem, 132), não se existe liberdade para se escolher entre igualdade e fraternidade, pois isso implicaria em abrir mão da propriedade privada e do lucro, o que aparentemente ninguém quer decidir.

Justiniano (2001) em Roma já falava de uma teoria do espelho atribuída a Marx, que afirma que o sistema jurídico é um reflexo das relações econômicas. Por exemplo, quanto a satisfação dos débitos para garantir a dívida, já lecionava Gaio, sobre a ideia de que só deverão ser vendidos os bens do executado, que se mostrarem suficientes para a satisfação dos seus débitos (idem, Digesto, 27, 10, 5). É o princípio da satisfatividade, informativo da tutela jurisdicional executiva previsto no artigo 659 do Código de Processo Civil Brasileiro em várias leis do ocidente. Além disso as questões de herança eram puramente materiais como no direito ocidental hoje e não mais patrimônio sentimental ligado ao nome. O direito sempre teve relação intima com 0 econômico. O que serve para uma análise do capital como regras imperiais de domínio, como aponta Miguez et allii (2012), pela qual o império capitalista a tudo domina.

Sociólogo, filósofo e mestre em filosofia pela UNESP, é doutorando em ciências sociais pela UNESP e doutorado em ciências da religião pela UMESP- Universidade Metodista de São Paulo, é professor na pós graduação de antropologia da Universidade do Sagrado Coração nas áreas de antropologia e Filosofia. Bolsista da CNPq. Brasileiro, residente em São Paulo - SP. 
Nessa lógica, elementos de direitos humanos, tal como vida e liberdade, tem menos valor que a propriedade. Até bem pouco tempo atrás, na história do Brasil e em alguns países, ainda persiste, a ideia de se ir preso por dívidas materiais, o que dá à liberdade um valor menor que a propriedade. Isto para não falar nas violentas retomadas de propriedade abalizadas pelo Estado, muitas vezes com mortes, fato do qual se depreende, que a vida tem menos valor do que propriedade.

\section{O lucro e o ídolo.}

O capitalismo usa sua fábrica de guerra e morte, mas tem um fim: o lucro (HARVEY, 2006). Ele supera suas crises com maquinas e mais máquinas de guerra, donde se produz mais lucro e impulsiona a indústria, Hinkelammert $(2005,193)$. Apontando para a triste inversão daqueles direitos humanos que pretendia Locke, mostra que os direitos não se propuseram à maioria dos homens, mas só à elite. Assim o capitalismo e a técnica, com sua máquina de guerra - como sua razão - produzem monstros, como diz o autor citando a famosa obra de Goya. Esses monstros são produzidos em uma estética de morte, corrupção, invencibilidade e domínio, ou seja, a própria essência da monstruosidade ainda é o capitalismo moderno. Ao se opor a certos valores, produz outros monstros, como o fundamentalismo.

O homem, que se deixou seduzir pela técnica, sendo a técnica uma relação na qual a ciência atende às formas de capitalismo, por fenômeno de ressentimento, as despreza e procura a afirmação de si mesmo na vontade de dominação do mundo, não mais visto como um meio para a realização dos valores mais altos, mas como fim em si mesmo: donde a civilização da técnica, serve ao industrialismo e ao capitalismo. Ferreti $(1972,12)$, estudioso de Benjamin afirma, analisando as obras de Scheler, o seguinte:

Logo não há mais plenitude de vida, não mais o amor para o mundo e para a plenitude de suas qualidades, não mais a autocontemplação desinteressa como objetivo real do homem, mas cálculo utilitarista com fim em si mesmo, redução da natureza ao seu aspecto exatamente mensurável e seguramente dominável, fanatismo do trabalho e do lucro, avaliação somente das qualidades humanas de diligência, rapidez, capacidade de adaptação, que possuem uma utilidade aos fins lucrativos.

Sociólogo, filósofo e mestre em filosofia pela UNESP, é doutorando em ciências sociais pela

UNESP e doutorado em ciências da religião pela UMESP- Universidade Metodista de São Paulo, é professor na pós graduação de antropologia da Universidade do Sagrado Coração nas áreas de antropologia e Filosofia. Bolsista da CNPq. Brasileiro, residente em São Paulo - SP. 
O nascimento da ciência moderna e a concepção mecanicista da natureza não são as causas, mas sim os efeitos dessa nova atitude, que consagrou a natureza, privando-a de Deus, da alma, de todo valor e qualidade.

Além da perda dos valores do espírito, a ciência e a técnica causaram um desgaste profundo nas relações humanas. Buber (2001) observou agudamente que, com o passar dos séculos, o mundo material se engrandeceu mais e mais, enquanto o mundo das relações pessoais pouco a pouco se restringiu. Um processo é a consequência do outro, visto que "o desenvolvimento da capacidade de experimentar e de utilizar cresce com a diminuição da capacidade do homem de criar uma relação dialógica" (BUBER, 2001, 45). Hoje, parece que a relação dialógica ficou menor, e que tenha cedido lugar àquela do domínio entre homens e de subjugação entre estes e a natureza e subjugando a próprio Deus.

Mitos são desconstruídos para dar lugar a outros não mais para explicar a vida, mas para subjugar a vida a um sistema cruel de poder. Porém outros mitos surgiram para dar certa razão ao modo de vida moderno. Para fazer uma consideração ao mito da caverna de Platão, em nossa sociedade apenas se enxerga o que se quer e não percebemos que somos escravos de nosso próprio desejo imposto por um sistema maior que nos prende a nós mesmos. A concepção Cristã nos convida a olhar o próximo e a transcender nossos desejos em prol de um bem comum. O pentecostal pode ter potencial para acreditar em uma mudança que a bíblia convida: deixar a lucratividade e viver uma ética mais cristã: Filipenses 3:7: "Mas o que, para mim, era lucro, isto considerei perda por causa de Cristo". Tem o potencial para viver assim mas recentemente assume uma teologia contraria, mais adaptada ao capital, a teologia da prosperidade.

\section{Os novos mitos}

Para Adorno, Benjamim não critica os mitos e as religiões pelo contráio, para Adorno a tarefa principal da filosofia de Benjamin é dar uma reconciliação do mito com a filosofia (1999, p. 30), não para adotar a explicação mitológica, mas para mostrar que ainda vivemos sobre mitos e que eles perfazem nossa vida. Ele na verdade quer superar o dualismo ontológico entre várias formas de conhecimento como arte, filosofia e ciências, e 
recompreender o valor da riqueza estética assim como a arte. E que o mito também tem sua riqueza estética e procura explicar muitas coisas.

A riqueza do mito não está na sua história em si, mas no seu poder de traduzir a realidade de um modo estético e que as pessoas assumem como verdade, mais do que a ciência. Vivemos para Benjamin, segundo Adorno, em mitos e artes ou melhor o mito e a arte tem mais força de explicação e de aceitação do que a ciência.

Segundo Hinkelammert $(2005,47)$, os mitos antagonizam a razão instrumental, porém a razão instrumental vive, quando do seu interesse, certos mitos tal como a mão invisível do mercado. $\mathrm{O}$ autor afirma que a modernidade cria mitos e é contra os mitos que se confundem com religião. A modernidade é contra os mitos gregos, mas cria mitos como o do progresso, do crescimento patológico, da democracia racial, da igualdade de oportunidade de igualdades, da verdade absoluta da ciência(que pretende explicar tudo) e vive segundo esses mitos. Os mitos segundo Campbell, são as histórias que conduzem nossas vidas, "Mitos são pistas para as potencialidades espirituais da vida humana" (CAMPBELL, 2007, 14) assim esses mitos, sobretudo o do progresso, é o que tem pautado a sociedade moderna. Não importa quem exclua ou quem deixe ferido, essa é a certeza que tem pautado nossa sociedade assim os sofrimentos e exclusões são justificados porque alguém disse que é assim que o mundo deve funcionar, é a própria essência do mito.

Um deles é que a ciência e o seu produto comercializável, as tecnologias, que foram apropriadas pelo capitalismo para gerar dinheiro, tem a potencialidade para resolver todos os problemas humanos. De comunicação a depressão, da produção material à fome, da impotência sexual ao deslocamento espacial, a tecnologia quer resolver todos os problemas, às vezes até os espirituais e emocionais através de remédios caros e globalizados.

A habilidade e a facilidade com que o homem cria técnicas sempre novas e mais perfeitas provocou nas gerações recentes uma confiança sem limites no progresso humano, nas possibilidades de levá-lo à frente até a realização do paraíso na terra e à feliz solução de todos os problemas e 
mistérios do homem. Mas é realmente verdade que as ciências e a técnica têm o poder de resolver todos os problemas e enigmas humanos? Não tem.

Aliado a toda manutenção de conhecimento único, surge a ideia de que conhecimento é poder (WESTHELLE, 2008) e que esse poder foi jungido ao capital e a serviço desse, ou seja a ciência foi submetida ao "interesse do capital" (PANIKKAR, 2005, 20), sendo assim o poder ao qual se refere é o próprio capital. Para entender o trunfo do capital sobre os valores antes religiosos, houve um triunfo da comunicação que trouxe e confirmou a modernidade.

Surgiram, no seio da modernidade, novas tecnologias da comunicação, produtos dessa ciência racionalizada, que levou o homem a um movimento de consumo desmedido e capitalizado. As pessoas passaram a ser valoradas não pela sua essência, e sim pela sua capacidade de consumo. Termos antes caros a humanidade como a teologia, alma, bondade, caridade não tiveram mais lugar.

A modernidade a tudo racionaliza. A tudo matematiza, a tudo contabiliza, a tudo registra de tal maneira, o homem fica reduzido a um negócio de contabilidade, que interessa particularmente aos registros das taxas e dos seguros (Steuerung und Sicherung), para utilizar uma expressão de Heidegger (2007, 113). A razão dita racionalizada que serve para equilibrar o mercado, nunca produziu tanta loucura. Quem não se encaixa no sistema e tem uma crise é considerado louco. Esse suposto diagnóstico só serve aos interesses do sistema de poder político e econômico estabelecido (FOUCAULT, 1990).

Assim a ideologia dominante capitalística com a proteção do Estado vai impor valores absolutos, papel antes atribuído a religião, e ao impor tais valores vai impor o querer e ao impor o querer vai lucrar com isso. A religião capitalística é feita por e pela burguesia dominante, que está na posição de capital cultural de impor seu pensamento aos outros e conta com o instrumental de comunicação da grande mídia de consumo para tanto. Assim as pessoas, as diferenças e a alteridade vão sendo construídas através de uma pratica discursiva da lógica dominante, da qual não há escapatória. 
Apenas mudando a prática discursiva através da revolução ou conscientização, da luta e da resistência é que se pode mudar o discurso, pois no final o discurso é a reprodução daquilo que pensamos, diz o sábio Jesus "porque a boca fala do que o coração está cheio." (BÍBLIA, Evangelho segundo Lucas 6:45). Assim assumimos e agimos conforme aquilo que pensamos e ainda pensamos o que nos é imposto por quem tem os instrumentais da pratica discursiva, de quem produz o saber e a verdade, tudo protegido pelo Estado.

Mas a luta pela diferença de pensar e de agir, fazer a diferença, agir diferente do que nos é imposto; é a condição para melhorar o mundo. Este só vai permanecer em boas ou más condições conforme as pessoas que fazem parte dele. A alteridade é essa relação em que o outro é pensado e se deve agir conforme a existência do outro. $\mathrm{Na}$ alteridade percebemos que outros estão fora das condições mínimas da humanidade, como falta de acesso à comida e justiças básicas. Quem está no poder até agora não pensou no outro, não existe até agora uma verdade, ou uma ciência que pense no outro, a religião cristã que deveria fazer pensar no outro foi e é constantemente cooptada pelo capitalismo através da teologia da prosperidade e pelo poder desde Constantino. Assim perde seu poder salvifico. O capital se torna mais forte do que a mensagem original pervertendo a religião. Através desses valores absolutos o capital se impõe para benefícios de poucos e para malefício de muitos, que ao desejarem o capital, não lutam contra ele. Não se luta contra religião, e ao assumir tais características religiosas, o capital garante sua permanência. Precisa-se de uma nova forma ideológica, uma que pense em igualdade, não prometida, mas efetiva, um pensamento-ato de pensar no outro, mas são as pessoas que fazem as práticas discursivas e precisa-se mudar o sistema atual. Resistamos. Só mudando os valores impostos, pensaremos no outro, como a mensagem não distorcida pelos homens de Jesus a Marx. Como? Fica para o despertar das consciências ou de classe ou de amor. Seja como for, falta uma consciência da relação.

\section{REFERÊNCIAS}

Sociólogo, filósofo e mestre em filosofia pela UNESP, é doutorando em ciências sociais pela UNESP e doutorado em ciências da religião pela UMESP- Universidade Metodista de São Paulo, é professor na pós graduação de antropologia da Universidade do Sagrado Coração nas áreas de antropologia e Filosofia. Bolsista da CNPq. Brasileiro, residente em São Paulo - SP. 
ADORNO, G, Letter's about Walter Benjamin, Alex Coles (ed.), Black Dog Publishing, London, 1999.

AGAMBEN, Giorgio. Permanente Emergência. Entrevista. Globo, Caderno Prosa e Verso, 4 dez. 2012. Disponível em http://www.ihu.unisinos.br/noticias/512966-giorgio-agamben acesso em 13/03/2014.

BÍBLIA. Bíblia Cristã Thompson de Estudo. Trad. João Ferreira de Almeida. Edição rev. e corrigida. Rio de Janeiro - RJ :CPAD-1995

BRESSER-PEREIRA, Luiz Carlos. As duas fases da história e as fases do capitalismo, Crítica e Sociedade: revista de cultura política. UFU, v.1, n.1, jan./jun. 2011. ISSN: 2237 - 0579. Acesso em 17/07/2015, disponível em: http://www.seer.ufu.br/index.php/criticasociedade/article/view/13505/7720

BENJAMIN, W. "Infância berlinense por volta de 1900"; tradução: Rubens Rodrigues Torres Filho e José Carlos Martins Barbosa, em: Obras escolhidas, v. II. São Paulo: Brasiliense, 1987

BENJAMIN, W. Paris, capital do século XIX; tradução: Rubens Rodrigues Torres Filho e José Carlos Martins Barbosa, em: Obras escolhidas, v. I. São Paulo: Brasiliense, 1991

BENJAMIN, W. Crítica da Violência - crítica do poder, in: Documentos de cultura, documentos de barbárie: escritos escolhidos. seleção e apresentação de Willi Bolle, trad. de Celeste H. M. Ribeiro de Souza et al., São Paulo, Cultrix/Editora da Universidade de São Paulo, 1991b.

BENJAMIN, Walter. A obra de arte na era de sua reprodutibilidade técnica. In: - Magia e Técnica: ensaios sobre literatura e história da cultura. Tradução de Sergio Paulo Rouanet. São Paulo: Brasiliense, 1994. p. $165-196$.

BENJAMIN, W. "As Afinidades Eletivas de Goethe". As afinidades electivas de Goethe", Walter Benjamin. Ensaios Reunidos: Escritos sobre Goethe, Rio de Janeiro 2011, pp. 11-15.

BENJAMIN, W. O capitalismo como religião. São Paulo: Boitempo editorial, 2013;

BENJAMIN, W. Destino e caráter in: O capitalismo como religião. São Paulo: Boitempo editorial, 2013b;

BENJAMIN, W. Escritos Sobre Mito e Linguagem. São Paulo: Editora 34/ Duas Cidades, 2011; Letícia Olano Morgantti Botelho 122 Pólemos, Brasília, vol. 1, n. 1, maio 2012

Sociólogo, filósofo e mestre em filosofia pela UNESP, é doutorando em ciências sociais pela UNESP e doutorado em ciências da religião pela UMESP- Universidade Metodista de São Paulo, é professor na pós graduação de antropologia da Universidade do Sagrado Coração nas áreas de antropologia e Filosofia. Bolsista da CNPq. Brasileiro, residente em São Paulo - SP. Email: joebarduzzi@yahoo.com.br 
BENJAMIN, W. Magia e Técnica, Arte e Política: Ensaios sobre literatura e história da cultura - Obras Escolhidas I. 5 a Edição. São Paulo: Editora Brasiliense, 1994;

BUBER, M. eu e vós, (original 1937), São Paulo, editora centauro, 2001.

CAMPBELL, J. Mitos, sonhos e religião. Trad. Ângela Lobo de Andrade e Bali Lobo de Andrade. Rio de Janeiro: Ediouro, 2001.

CASSIRER, Ernst. Antropologia Filosófica. São Paulo: Mestre Jou, 1977.

DURKHEIM, E. As formas elementares da vida religiosa. São Paulo: Martins Fontes, 2000.

FERRETI G. (1982). Max Scheler, fenomenologia e antropologia personalistica, Vita e pensiero, Milão, 1972, Trad. EDUSP

FOUCAULT, M. Microfísica do poder. 9.ed. Rio de Janeiro: Graal, 1990.

HARVEY, David. A produção capitalista do espaço. São Paulo: Annablume, 2006

HEIDEGGER, Martin. (2007) Nietzsche - volume II. Tradução: Marco Antônio Casanova. Rio de Janeiro: Forense Universitária.

HINKELAMMERT, Franz J. Hacia una crítica de la razón mítica: el labirinto de la modernidade. México: Editorial Driada, 2008.

HOFFMANN, R. Distribuição de renda: medidas de desigualdade e pobreza. São Paulo: EDUSP, 1998.

JUSTINIANO, Flavius Petrus Sabbatitus. Institutas. Trad. Edson Bini São Paulo, Edipro, 2001.

MESSNER, S. F.; ROSENFELD, R., Crime and the American Dream. Belmont: Wadsworth, 2000.

MíGUEZ, Néstor. RIEGER, Joerg, SUNG, Jung Mo. Para além do espírito do império: novas perspectivas em política religião. São Paulo: Paulinas, 2012.

PANIKKAR, Raimon. Morte e ressurreição da Teologia, Revista Horizontes, Belo Horizonte, v. 4, n. 7, p. 15-29, dez. 2005, disponível em: http://periodicos.pucminas.br/index.php/horizonte/article/view/525, acesso em $12 / 0 / 2015$

VERNANT, J.P. O Universo, os Deuses, os Homens. Trad. Rosa Freire d'Aguiar. SP: Companhia das Letras, 2010.

WESTHELLE, Vitor (2008) - Traumas e Opções: Teologia e a Crise Da Modernidade. Publicações do centro de estudos anglicanos, disponível em

Sociólogo, filósofo e mestre em filosofia pela UNESP, é doutorando em ciências sociais pela UNESP e doutorado em ciências da religião pela UMESP- Universidade Metodista de São Paulo, é professor na pós graduação de antropologia da Universidade do Sagrado Coração nas áreas de antropologia e Filosofia. Bolsista da CNPq. Brasileiro, residente em São Paulo - SP. Email: joebarduzzi@yahoo.com.br 
http://www.centroestudosanglicanos.com.br/bancodetextos/diversos/teologia $\mathrm{cr}$ ise modernidade vitor.pdf, publicado em 14/out/2008, consultado em 30/mar/2013.

Sociólogo, filósofo e mestre em filosofia pela UNESP, é doutorando em ciências sociais pela UNESP e doutorado em ciências da religião pela UMESP- Universidade Metodista de São Paulo, é professor na pós graduação de antropologia da Universidade do Sagrado Coração nas áreas de antropologia e Filosofia. Bolsista da CNPq. Brasileiro, residente em São Paulo - SP. Email: joebarduzzi@yahoo.com.br 